The Canadian Mineralogist

Vol. 38, pp. 649-656 (2000)

\title{
THE CRYSTAL STRUCTURE OF YOSHIMURAITE, A LAYERED Ba-Mn-Ti SILICOPHOSPHATE, WITH COMMENTS ON FIVE-COORDINATED $\mathrm{Ti}^{4+}$
}

\author{
ANDREW M. McDONALD $\$$ \\ Department of Earth Sciences, Laurentian University, Sudbury, Ontario P3E 2C6, Canada
}

JOEL D. GRICE

Research Division, Canadian Museum of Nature, P.O. Box 3443, Station D, Ottawa, Ontario K1P 6P4, Canada

GEORGE Y. CHAO*

Department of Earth Sciences, Ottawa-Carleton Geoscience Centre, Carleton University, Ottawa, Ontario K1S 5B6, Canada

ABSTRACT

The crystal structure of yoshimuraite, ideally $\mathrm{Ba}_{2} \mathrm{Mn}_{2} \mathrm{TiO}\left(\mathrm{Si}_{2} \mathrm{O}_{7}\right)\left(\mathrm{PO}_{4}\right)(\mathrm{OH})$, has been determined and refined to residuals of $R=3.0 \%$ and $w R=4.1 \%$ using material from the Taguchi mine, Aichi Prefecture, Honshu, Japan. It is triclinic, $P \overline{1}$, with cell parameters $a$ 5.386(1), b 6.999(1), c 14.748(3) $\AA$, $\alpha$ 89.98(1), $\beta$ 93.62(2), $\gamma 95.50(2) \%, V$ 552.3(1) $\AA^{3}$, with $Z=2$. The mineral is strongly layered on (001), consisting of two quasi-tetrahedral layers composed of $\mathrm{TiO}_{5}$ polyhedra cross-linked by cornersharing $\left(\mathrm{Si}_{2} \mathrm{O}_{7}\right)$ clusters. These layers bound on two sides a layer of closest-packed Mn $\phi_{6}$ octahedra, thus forming a composite unit reminiscent of that found in 2:1 phyllosilicates. Such composite units are subsequently linked along [001] via an interlayerlike $\left[\mathrm{Ba}_{2}\left(\mathrm{PO}_{4}\right)\right]$ sheet, the bonding between the two being relatively weak and resulting in the pronounced $\{001\}$ cleavage observed in the mineral. Yoshimuraite is a member of the $B M_{n}$ heterophyllosilicate polysomatic series [specifically, the $B M_{0}$ polysome series], which includes phases such as astrophyllite, bafertisite and seidozerite.

Keywords: yoshimuraite, barium manganese titanium silicophosphate hydrate, heterophyllosilicate polysomatic series, Taguchi mine, Japan.

\section{SOMMAIRE}

Nous avons résolu la structure cristalline de la yoshimuraïte, dont la composition idéale est $\mathrm{Ba}_{2} \mathrm{Mn}_{2} \mathrm{TiO}\left(\mathrm{Si}_{2} \mathrm{O}_{7}\right)\left(\mathrm{PO}_{4}\right)(\mathrm{OH})$, jusqu'à un résidu $R$ de $3.0 \%(w R=4.1 \%)$ en utilisant un échantillon de la mine Taguchi, préfecture d'Aichi, île de Honshu, au Japon. Il s'agit d'un minéral triclinique, $P 1$, dont les paramètres réticulaires sont $a 5.386(1), b 6.999(1), c 14.748(3) \AA$ ( $\alpha 89.98(1)$, $\beta$ 93.62(2), $\gamma 95.50(2) \%, V 552.3(1) \AA^{3}$, avec $Z=2$. La yoshimuraïte possède des feuillets (100) prominents, et contient de couches quasi-tétraédriques contenant des polyèdres $\mathrm{TiO}_{5}$ liés entre eux par des groupes $\left(\mathrm{Si}_{2} \mathrm{O}_{7}\right)$ à coins partagés. Ces feuillets sont disposés de chaque côté d'une couche d'octaèdres Mn $\phi_{6}$ à agencement compact, agencement composite ressemblant à celui des phyllosilicates 2:1. De tels feuillets sont liés entre eux le long de [001] par un inter-feuillet de $\left[\mathrm{Ba}_{2}\left(\mathrm{PO}_{4}\right)\right]$; les liaisons entre les deux composants sont relativement faibles, ce qui rend compte du clivage $\{001\}$ prononcé. La yoshimuraïte fait partie de la série polysomatique $B M_{n}$ dite hétérophyllosilicate, et en particulier de la série des polysomes $B M_{0}$, qui inclut les espèces astrophyllite, bafertisite et seidozerite.

(Traduit par la Rédaction)

Mots-clés: yoshimuraïte, silicophosphate de baryum, manganèse et titane hydraté, série polysomatique hétérophyllosilicatée, mine Taguchi, Japon.

§ E-mail address: amcdonal@nickel.laurentian.ca

* Present address: 2031 Delmar Drive, Ottawa, Ontario K1H 5P6, Canada. 


\section{INTRODUCTION}

Yoshimuraite, $\mathrm{Ba}_{2} \mathrm{Mn}_{2} \mathrm{TiO}\left(\mathrm{Si}_{2} \mathrm{O}_{7}\right)\left(\mathrm{PO}_{4}\right)(\mathrm{OH})$, was originally described from the Noda-Tamagawa mine, Iwate Prefecture, Honshu, Japan, where it occurs in alkali syenite pegmatites located between a manganiferous hornfels unit and a layered Mn orebody (Watanabe et al. 1961). It was subsequently found in samples from the Taguchi mine, Aichi Prefecture, Honshu, Japan, where it occurs in orange-brown platy to tabular crystals, with Mn-bearing aegirine and rhodonite. Its structure has been solved and refined to evaluate the extent to which Si and P are ordered, and to investigate its crystal-chemical relationship with other layered Ti-bearing silicates.

\section{Chemical Composition}

The material used in this study is from the Taguchi mine; it was obtained from the National Mineral Collection of Canada at the Geological Survey of Canada (NMC 63546). In order to confirm the chemical composition of the yoshumuraite used in this study, wavelength-dispersion data were collected on a Cambridge Microscan MK5 electron microprobe using an operating voltage of $15 \mathrm{kV}$ and an estimated beam-current of $30 \mathrm{nA}$. The following standards were used: $\mathrm{Ba}-\mathrm{Si}$ glass $(\mathrm{Ba} L \alpha)$, celestine $(\mathrm{Sr} L \alpha, \mathrm{S} K \alpha)$, Kakanui hornblende ( $\mathrm{Ti} K \alpha, \mathrm{Si} K \alpha, \mathrm{Fe} K \alpha, \mathrm{Mg} K \alpha)$, and fluorapatite $(\mathrm{P} K \alpha)$. Also sought but not detected were $\mathrm{Na}, \mathrm{K}, \mathrm{Ca}, \mathrm{Al}, \mathrm{Nb}, \mathrm{Cl}$ and F. Analytical results are provided in Table 1 . The average composition gives the empirical formula (based on 13 atoms of oxygen, as determined from results of the crystal structure analysis): $\left(\mathrm{Ba}_{1.95} \mathrm{Sr}_{0.28}\right)_{\Sigma 2.23}$ $\left(\mathrm{Mn}_{1.64} \mathrm{Fe}_{0.49} \mathrm{Mg}_{0.03}\right)_{\Sigma 2.16}\left(\mathrm{Ti}_{0.78} \mathrm{Fe}_{0.22}\right)_{\Sigma 1} \mathrm{O}\left(\mathrm{Si}_{2} \mathrm{O}_{7}\right)$ $\left[\left(\mathrm{P}_{0.46} \mathrm{~S}_{0.34} \mathrm{Si}_{0.17}\right)_{\Sigma 0.97} \mathrm{O}_{4}\right](\mathrm{OH})$, which suggests the essentially ordered occurrence of $\mathrm{Si}^{4+}$ and confirms a

TABLE 1. CHEMICAL COMPOSITION OF YOSHIMURAITE

\begin{tabular}{lrrrrrrr}
\hline & 1 & 2 & 3 & 4 & 5 & 6 & 7 \\
& & & & & & & \\
& & & & & & & \\
$\mathrm{BaO} w \mathrm{w} \%$ & 39.75 & 39.29 & 38.95 & 38.34 & 39.08 & 33.51 & 42.09 \\
$\mathrm{SrO}$ & 2.64 & 3.05 & 3.19 & 3.16 & 3.01 & 4.62 & - \\
$\mathrm{MnO}$ & 15.27 & 15.11 & 15.01 & 15.22 & 15.15 & 17.64 & 19.47 \\
$\mathrm{TiO}_{2}$ & 8.46 & 8.27 & 7.88 & 7.86 & 8.12 & 10.00 & 10.97 \\
$\mathrm{Fe}_{2} \mathrm{O}_{3}$ & 7.85 & 7.95 & 8.29 & 8.06 & 8.04 & 1.32 & - \\
$\mathrm{MgO}$ & 0.13 & 0.12 & 0.24 & 0.22 & 0.18 & 0.56 & - \\
$\mathrm{SiO}_{2}$ & 16.96 & 16.83 & 16.97 & 17.22 & 17.00 & 18.25 & 16.49 \\
$\mathrm{P}_{2} \mathrm{O}_{5}$ & 4.37 & 4.19 & 4.01 & 4.28 & 4.21 & 3.98 & 9.74 \\
$\mathrm{SO}_{3}$ & 3.56 & 3.84 & 4.02 & 4.28 & 3.92 & 5.40 & - \\
$\mathrm{H}_{2} \mathrm{O}$ & $(1.24)$ & $(1.23)$ & $(1.23)$ & $(1.23)$ & $(1.23)$ & $(2.34)$ & 1.24 \\
& & & & & & & \\
$\mathrm{Total}$ & 100.23 & 99.88 & 99.79 & 99.00 & 99.94 & 100.10 & 100 \\
\hline
\end{tabular}

Column 5: Average of compositions 1-4 determined on one grain.

Column 6: Data reported by Watanabe et al. (1961) for yoshimuraite from the Noda-Tamagawa mine. The total includes $1.47 \%$ FeO (by weight), $0.50 \% \mathrm{ZnO}$, $0.16 \% \mathrm{Na}_{2} \mathrm{O}, 0.03 \% \mathrm{~K}_{2} \mathrm{O}, 0.41 \% \mathrm{Cl}$ and $\mathrm{O}=\mathrm{Cl}-0.09$.

Column 7: Composition calculated for ideal formula, $\mathrm{Ba}_{2} \mathrm{Mn}_{2} \mathrm{TiO}\left(\mathrm{Si}_{2} \mathrm{O}_{7}\right)\left(\mathrm{PO}_{4}\right)(\mathrm{OH})$. preponderance of $\mathrm{P}^{5+}$ over $\mathrm{S}^{6+}$ in the isolated tetrahedral site.

\section{X-Ray Crystallography and Crystal-Structure Determination}

For X-ray-diffraction intensity data, a plate measuring $0.09 \times 0.06 \times 0.04 \mathrm{~mm}$ was selected. Although Watanabe et al. (1961) indicated that the crystals of yoshimuraite examined by them all exhibit what they interpreted to be polysynthetic twinning on $\{001\}$ (twin law unknown), the crystal used in this present study shows no evidence of such twinning after being studied by optical microscopy and X-ray-precession techniques. Single-crystal X-ray-precession photographs confirm that the mineral is triclinic, with possible space-groups $P 1$ and $P \overline{1}$. Intensity data were collected on a fully automated Nicolet $R 3 m$ four-circle diffractometer. A set of 25 reflections was used to orient the crystal and to refine the cell dimensions. Intensity data were collected out to $2 \theta=60^{\circ}$ using the $\theta: 2 \theta$ scan mode and a scan range of $2^{\circ}$. A variable scan-rate inversely proportional to the peak intensity was used, with maximum and minimum scan-rates of $29.3^{\circ} 2 \theta / \mathrm{min}$ and $4.0^{\circ} 2 \theta / \mathrm{min}$, respectively. Data pertinent to the collection of the intensity data are given in Table 2.

The data were subsequently corrected for Lorentz, polarization, background effects and absorption and reduced to structure factors using the SHELXTL PC (Sheldrick 1990) package of computer programs. For the ellipsoidal absorption correction, eleven intense diffraction-maxima in the range of 10 to $53^{\circ} 2 \theta$ were selected for $\Psi$ diffraction-vector scans (North et al. 1968).

TABLE 2. MISCELLANEOUS INFORMATION FOR YOSHIMURAITE

\begin{tabular}{|c|c|c|c|}
\hline Space Group & $p_{1}^{\top}\left(H_{2}\right)$ & Diffractometer & Nicolet $R 3 m$ \\
\hline$a(\AA)$ & $5.386(1)^{*}$ & Radiation & $\operatorname{MoK} \alpha(50 \mathrm{kV}, 40 \mathrm{~mA})$ \\
\hline$b$ & $6.999(1)^{*}$ & Monochromator & Graphite \\
\hline$c$ & $14.748(3)^{*}$ & Crystal shape & $\begin{array}{l}\text { Plate, flattened on } \\
\{001\}\end{array}$ \\
\hline$\alpha\left({ }^{\circ}\right)$ & $89.98(1)^{\prime \prime}$ & Crystal size & $0.09 \times 0.06 \times 0.04 \mathrm{~mm}$ \\
\hline$\beta$ & $93.62(2)^{*}$ & $\mu(\mathrm{MoK} \alpha)$ & $10.94 \mathrm{~mm}^{-1}$ \\
\hline$\gamma$ & $95,50(2)^{*}$ & $Z$ & 2 \\
\hline$V\left(\AA^{3}\right)$ & $552.3(1)$ & & \\
\hline \multicolumn{2}{|c|}{ Chemical formula } & \multicolumn{2}{|c|}{$\mathrm{Ba}_{2} \mathrm{Mn}_{2} \mathrm{TiO}\left(\mathrm{Si}_{2} \mathrm{O}_{7}\right)\left(\mathrm{PO}_{4}\right)(\mathrm{OH})$} \\
\hline \multicolumn{2}{|c|}{ Intensity-data collection } & \multicolumn{2}{|c|}{$\theta-2 \theta$ scan mode } \\
\hline \multicolumn{2}{|c|}{$2 \theta$ limit } & \multicolumn{2}{|l|}{$55^{\circ}$} \\
\hline \multicolumn{2}{|c|}{ Intensity standards } & \multicolumn{2}{|c|}{ Two every 58 reflections } \\
\hline \multicolumn{2}{|c|}{ Ortentation standards } & \multicolumn{2}{|c|}{ Two every 58 reflections } \\
\hline \multicolumn{2}{|c|}{ Number of unique reflections } & \multicolumn{2}{|c|}{2353} \\
\hline \multicolumn{2}{|c|}{ Number of observed reflections } & \multicolumn{2}{|l|}{1842} \\
\hline \multicolumn{2}{|c|}{ Criterion for observed reflection } & \multicolumn{2}{|c|}{$F>60(F)$} \\
\hline \multicolumn{2}{|c|}{ Weighting scheme } & \multicolumn{2}{|c|}{$w R=\left[\sum w\left(F_{o}-F_{c}\right)^{2} / \Sigma w F_{o}^{2}\right]^{1 / 2}, \quad w=1 / \sigma^{2}$} \\
\hline \multicolumn{2}{|c|}{ Final $R$ for all observed reflections } & \multicolumn{2}{|c|}{$3.0 \%$} \\
\hline \multicolumn{2}{|c|}{ Final $w R$ for all observed reflections } & \multicolumn{2}{|l|}{$4.1 \%$} \\
\hline
\end{tabular}

* values refined from four-circle diffractometer data. 
This approach reduced the $R$ (azimuthal) from 4.59 to $2.09 \%$ and resulted in minimum and maximum values of transmission of 0.624 and 0.815 , respectively. There was no appreciable deterioration of the crystal due to radiation damage during the experiment.

The structure was solved using Patterson methods, and the refinement was done with the SHELXTL PC (Sheldrick 1990) package of computer programs. Phasing of a set of normalized structure-factors gave a mean $\left|E^{2}-1\right|$ value of 0.968 , suggesting the centrosymmetric space-group $P \overline{1}$ as the most probable choice. A sharpened Patterson map was calculated, from which the positions of all the major cations and eleven $\mathrm{O}^{2-}$ atoms were identified. This model refined to $R=9.9 \%$ and $w R$ $=10.7 \%$. Subsequent difference-Fourier maps revealed the positions of the two additional $\mathrm{O}^{2-}$ atoms. Refinement of this model included conversion to anisotropic displacement-factors, introduction of a weighting scheme based on $\left[1 / \sigma^{2}\left(F_{0}\right)\right]$, and modification of the scattering factor for the site assigned to $\mathrm{P}^{5+}$ to $\left(\mathrm{P}_{0.5} \mathrm{~S}_{0.3} \mathrm{Si}_{0.2}\right)_{\Sigma 1.0}$ to be consistent with the electron-microprobe data. Furthermore, least-squares refinement of the site occupancy for the Ti site converged to 0.69 (3) $\mathrm{Ti}$ and $0.31(3) \mathrm{Fe}$; in good agreement with the electronmicroprobe results (Table 1). This model converged to $R=3.0 \%$ and $w R=4.1 \%$ for 1842 observed reflections $\left[F>6 \sigma\left(F_{\mathrm{o}}\right)\right]$. No improvement in the final residual was noted when an extinction condition was included, and the final difference-map showed no maxima greater than $1 e^{-} / \AA^{3}$.

Final positional and thermal parameters are presented in Table 3, selected bond-lengths and angles, in Table 4, and calculated bond-valence sums, in Table 5. Observed and calculated structure-factors are available from the Depository of Unpublished Data, CISTI, Na- tional Research Council of Canada, Ottawa, Ontario K1A 0S2, Canada.

\section{Description of the Structure}

The structure of yoshimuraite is layered on (001). It contains a heterophyllosilicate layer (Ferraris et al. 1996) of composition $\left[\mathrm{TiSi}_{2} \mathrm{O}_{8}\right]^{4-}$ formed from $\mathrm{TiO}_{5}$ polyhedra cross-linked with corner-sharing $\left(\mathrm{Si}_{2} \mathrm{O}_{7}\right)$ clusters (Fig. 1). A layer of closest-packed octahedra $(O)$, composed of three crystallographically distinct edge-

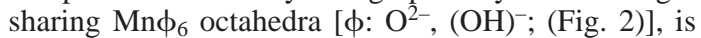
surrounded on two sides by heterophyllosilicate layers, producing a 2:1 composite unit reminiscent of that found in 2:1 phyllosilicates (Fig. 3). Linkages between the heterophyllosilicate layers and the $O$ layers occur through apical $\mathrm{O}^{2-}$ of the $\mathrm{TiO}_{5}$ and $\mathrm{SiO}_{4}$ polyhedra, and misfit results in the slightly divergent apical arrangement evident in the two crystallographically distinct $\mathrm{SiO}_{4}$ tetrahedra (Fig. 3). Along the $c$ axis and interleaving between adjacent 2:1 composite sheets is a $\left[\mathrm{Ba}_{2}\left(\mathrm{PO}_{4}\right)\right]$ polyhedral layer (Fig. 3). This interlayer unit is composed of non-polymerized $\mathrm{PO}_{4}$ tetrahedra joined to $\mathrm{BaO}_{11}$ polyhedra through both shared edges and faces. Some relatively distant $\mathrm{O}^{2-}$ atoms (i.e., >3 $\AA$ ) have been included in the $\mathrm{BaO}_{11}$ polyhedra, which may explain the high bond-valence summations for $\mathrm{Ba}(1)$ and $\mathrm{Ba}(2)$ (Table 5). The interlayer-like $\left[\mathrm{Ba}_{2}\left(\mathrm{PO}_{4}\right)\right]$ polyhedral layer is very similar to that found in the barite structure, where layers of $\mathrm{SO}_{4}$ tetrahedra alternate with layers of $\mathrm{BaO}_{12}$ polyhedra (Hill 1977). In yoshimuraite, weak bonding between the 2:1 composite unit and the $\left[\mathrm{Ba}_{2}\left(\mathrm{PO}_{4}\right)\right]$ polyhedral layer probably results in the distinct $\{001\}$ cleavage observed in the mineral. The mineral is most closely related on a structural

TABLE 3. POSITIONAL AND THERMAL PARAMETERS FOR YOSHIMURAITE

\begin{tabular}{|c|c|c|c|c|c|c|c|c|c|c|}
\hline & $x$ & $y$ & $z$ & $U_{11}$ & $U_{22}$ & $U_{33}$ & $U_{13}$ & $U_{12}$ & $U_{23}$ & $U_{\alpha_{1}}$ \\
\hline $\mathrm{Ba}(1)$ & $0.22065(9)$ & $0.33664(7)$ & $0.32839(4)$ & $160(2)$ & $166(2)$ & $256(3)$ & $13(2)$ & $8(2)$ & $97(2)$ & $189(2)$ \\
\hline $\mathrm{Ba}(2)$ & $0.73074(8)$ & $0.82198(6)$ & $0.39244(3)$ & $157(2)$ & $112(2)$ & $120(2)$ & $4(2)$ & $O(2)$ & $5(2)$ & $130(1)$ \\
\hline $\operatorname{Mn}(1)$ & 0 & 0 & 0 & $90(7)$ & $95(7)$ & $192(8)$ & $46(6)$ & $-18(5)$ & $-11(6)$ & $126(4)$ \\
\hline $\operatorname{Mn}(2)$ & $0.4993(2)$ & $0.2482(2)$ & $0.99516(8)$ & $91(6)$ & $76(5)$ & $125(6)$ & $4(4)$ & $-6(4)$ & $0(4)$ & $98(3)$ \\
\hline $\mathrm{Mn}(3)$ & 0 & $1 / 2$ & 0 & $132(8)$ & $163(8)$ & $265(1)$ & $84(7)$ & $42(6)$ & $83(7)$ & $179(5)$ \\
\hline $\mathrm{Ti}$ & $0.1990(2)$ & $0.7948(2)$ & $0.2028(1)$ & $30(6)$ & $74(6)$ & $101(6)$ & $-2(4)$ & $-3(4)$ & $0(4)$ & $69(3)$ \\
\hline Si(1) & $0.6949(3)$ & $0.0644(2)$ & $0.1881(1)$ & $32(8)$ & $24(8)$ & $74(8)$ & $-7(6)$ & $-9(6)$ & $-8(6)$ & $44(5)$ \\
\hline $\operatorname{Si}(2)$ & $0.6955(3)$ & $0.5130(2)$ & $0.1852(1)$ & $50(8)$ & $26(8)$ & $65(8)$ & $6(6)$ & $-6(6)$ & $0(6)$ & $47(5)$ \\
\hline $\mathbf{P}$ & $0.2537(4)$ & $0.7181(3)$ & $0.5229(2)$ & $129(12)$ & $138(12)$ & $197(14)$ & $2(9)$ & $3(8)$ & $4(9)$ & $156(8)$ \\
\hline$O(1)$ & $0.2364(12)$ & $0.6897(10)$ & $0.4190(5)$ & $233(32)$ & $438(39)$ & $210(34)$ & $63(27)$ & $-2(29)$ & $-62(29)$ & $297(21)$ \\
\hline$O(2)$ & $0.9527(9)$ & $0.6080(8)$ & $0.2322(4)$ & $107(24)$ & $267(29)$ & $63(24)$ & $34(19)$ & $94(21)$ & $26(22)$ & $144(15)$ \\
\hline$O(3)$ & $0.9527(9)$ & $0.9905(8)$ & $0.2353(4)$ & $88(24)$ & $284(3)$ & $108(26)$ & $-73(20)$ & $136(2 \mathrm{l})$ & $-54(23)$ & $168(16)$ \\
\hline$O(4)$ & $0.4561(9)$ & $0.9918(8)$ & $0.2365(4)$ & $158(27)$ & $283(30)$ & $6(25)$ & $61(21)$ & $-121(22)$ & $-17(22)$ & $169(16)$ \\
\hline$O(5)$ & $0.9510(10)$ & $0.6079(8)$ & $0.2309(4)$ & $98(24)$ & $262(30)$ & $125(27)$ & $-26(20)$ & $-10(21)$ & $40(23)$ & $162(17)$ \\
\hline$O(6)$ & $0.0376(10)$ & $0.8286(8)$ & $0.5536(4)$ & $137(26)$ & $263(30)$ & $160(29)$ & $8(22)$ & $-24(22)$ & $25(24)$ & $186(17)$ \\
\hline$O(7)$ & $0.5180(10)$ & $0.1718(8)$ & $0.4476(4)$ & $151(26)$ & $238(30)$ & $142(28)$ & $13(22)$ & $38(22)$ & $-9(23)$ & $179(17)$ \\
\hline$O(8)$ & $0.3254(9)$ & $0.4886(7)$ & $0.9247(3)$ & $113(23)$ & $91(22)$ & $57(22)$ & $-41(18)$ & $21(18)$ & $8(18)$ & $89(13)$ \\
\hline$O(9)$ & $0.1834(9)$ & $0.7720(7)$ & $0.0818(4)$ & $59(22)$ & $106(23)$ & $133(25)$ & $7(19)$ & $16(18)$ & $5(19)$ & $100(14)$ \\
\hline$O(10)$ & $0.6974(13)$ & $0.2960(7)$ & $0.2149(4)$ & $505(39)$ & $36(23)$ & $114(27)$ & $29(26)$ & $-42(23)$ & $-4(20)$ & $218(18)$ \\
\hline$O(11)$ & $0.1731(10)$ & $0.2622(7)$ & $0.0666(4)$ & $121(24)$ & $116(24)$ & $169(27)$ & $21(21)$ & $-25(19)$ & $8(20)$ & $135(15)$ \\
\hline$O(12)$ & $0.6736(8)$ & $0.0174(7)$ & $0.0782(3)$ & $39(21)$ & $109(22)$ & $69(23)$ & $6(18)$ & $-14(17)$ & $-3(18)$ & $73(13)$ \\
\hline$O(13)$ & $0.2624(14)$ & $0.5397(10)$ & $0.5703(6)$ & $370(40)$ & 204(33) & $628(54)$ & $72(37)$ & $-8(28)$ & $169(34)$ & $390(25)$ \\
\hline
\end{tabular}

Note: Anisotropic temperature factors have the form $\exp \left[-2 \pi^{2}\left(h^{2} a^{{ }^{2}} U_{11}+k^{2} b^{2 / 2} U_{22} .2 h k a^{{ }_{2} 2} b^{* 2} U_{12}\right] ;\right.$ all $U$ values are in $\mathrm{A}^{2} \times 10^{4}$; estimated standard deviations in parentheses. 
TABLE 4. SELECTED INTERATOMIC DISTANCES (A) ANI) BONI) ANGIES $\left(^{\circ}\right)$ IN YOSHDMURAI'TE

\begin{tabular}{|c|c|c|c|}
\hline \multicolumn{4}{|c|}{ Bal Polyhedron } \\
\hline \multirow[t]{11}{*}{$\mathrm{Ba}(1)$} & -06 & & $2.645(6)$ \\
\hline & -07 & & $2.650(6)$ \\
\hline & - OI & & $2.693(7)$ \\
\hline & - $\mathrm{O} 2$ & & $2.827(6)$ \\
\hline & - 05 & & $2.835(6)$ \\
\hline & - $\mathrm{O} 4$ & & $2.976(6)$ \\
\hline & -03 & & $2.992(5)$ \\
\hline & -010 & & $3.151(7)$ \\
\hline & -013 & & $3.156(7)$ \\
\hline & $-013^{\prime}$ & & $3.161(8)$ \\
\hline & $-010^{\prime}$ & & $3.184(6)$ \\
\hline$<\mathrm{Ba} 1$ & $-0>$ & & 2.934 \\
\hline \multicolumn{4}{|c|}{ Mn1 Octahedron } \\
\hline Mn 1 & -012 & $x 2$ & $2.160(5)$ \\
\hline - & 011 & $\mathrm{x} 2$ & $2.177(5)$ \\
\hline & -09 & $\times 2$ & $\underline{2.279}(5)$ \\
\hline$<$ Mn1 & $-0>$ & & $\overline{2.205}$ \\
\hline \multicolumn{4}{|c|}{ Mo2. Octahedron } \\
\hline $\mathrm{Mn} 2$ & -011 & & $2.103(6)$ \\
\hline & -09 & & $2.108(5)$ \\
\hline & $-012^{1}$ & & $2.232(5)$ \\
\hline & -08 & & $2.236(5)$ \\
\hline & $-08^{\prime}$ & & $2.264(5)$ \\
\hline & -012 & & $2.286(5)$ \\
\hline$<\mathrm{Mn} 2$ & $-0>$ & & 2.205 \\
\hline
\end{tabular}

Ba2 Polyhedron

$\mathrm{Ba} 2-\mathrm{O} 13$

- $06^{\circ}$

- 07

$-07$

- 06

- $\mathrm{Ol}$

$-01$

- 02

$-04$

$-05$

-03
$-O$
Mn3 Octahedron

$\mathrm{Mn} 3$ - O8 $\times 2$ 2.131(5)

- $011 \times 22.191(5)$

- $09 \times 2 \underline{2.338(5)}$

$4 \mathrm{Mn} 3-\mathrm{O}>\quad 2.220$

Ti Tetragonal pyramid
$\begin{array}{rll}\text { Ti } & - \text { O9 } & 1.773(6) \\ & -03 & 1.954(6) \\ & -05 & 1.960(6) \\ & -O 4 & 1.962(6) \\ & -O 2 & \underline{1.967(6)} \\ \mathrm{Ti} & -\mathrm{O}> & 1.923\end{array}$

Sil Tetrahedron

Sil - O4 1.615(6)

- $012 \quad 1.620(6)$

- $03 \quad 1.621(6)$

- $010 \quad 1.631(6)$

$\measuredangle S i 1-O>1.622$

Si2 Tetrahedron

Si2 $-05 \quad 1.608(5)$

- $02 \quad 1.609(6)$

- $08 \quad 1.616(5)$

- $010 \quad 1.621(6)$

$\langle\mathrm{Si} 2-0\rangle \quad 1.614$

$P$ Tetrahedron

$\begin{array}{lll}\mathrm{P} & -\mathrm{O} 6 & 1.468(6)\end{array}$

$\begin{array}{ll}-06 & 1.468(6) \\ -07 & 1.471(6)\end{array}$

- $013 \quad 1.488(8)$

- $01 \quad 1.522(7)$

1.487
$2.641(7)$

$2.771(6)$

$2.776(6)$

$2.782(6)$

2.804(6)

$2.881(6)$

$2.892(6)$

$2.979(5)$

$2.996(6)$

$3.000(5)$

$3.011(6)$

$<\mathrm{Ba} 2-\mathrm{O} \quad 2.867$
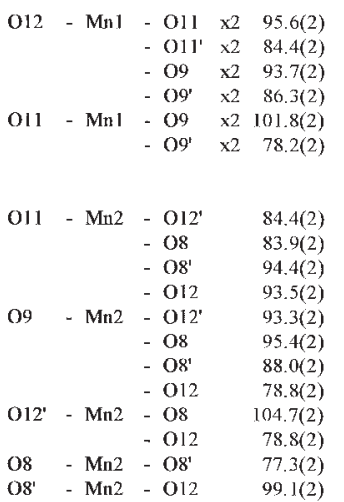

$08-\mathrm{Mn3} \quad-011 \quad \times 2 \quad 83.3(2)$

- $O(9) \times 2 \quad 85.5(2)$

$\mathrm{O8}^{1}-\mathrm{Mn} 3-011 \quad \times 2 \quad 95.7(2)$

$\begin{array}{rlll}-09 & \times 2 & 94.5(2)\end{array}$

$011-M_{n} 3-09 \quad x 2 \quad 103.3(2)$

$\mathrm{O}^{\prime}-\mathrm{Mn3}-\mathrm{O}^{\prime} \quad \mathrm{x} 2 \quad 76.7(2)$

O9 $\quad-\mathrm{Ti} \quad-\mathrm{O} 3 \quad 104.5(2)$

$\begin{array}{ll}-05 & 103.0(2)\end{array}$

$103.7(2)$

$102.3(2)$

$86.1(2)$

$87.6(2)$

$88.0(2)$

$$
\begin{array}{llll}
\mathrm{O} 4 & -\mathrm{Ti} & -\mathrm{O} 2 & 86.0(2)
\end{array}
$$

$04-\mathrm{Si1}-012 \quad 113.1(3)$

- $03 \quad 111.6(3)$

$\begin{array}{lll}-010 & 103.6(3)\end{array}$

$\begin{array}{rll}012-\mathrm{Si1} & -\mathrm{O} 3 & 113.0(3) \\ & -010 & 110.1(3)\end{array}$

$03-\mathrm{Sil}-010 \quad 104.6(3)$

$05-\mathrm{Si} 2-02 \quad 111.5(3)$

$\begin{array}{ll}-08 & 112.7(3) \\ -010 & 1048(3)\end{array}$

$\begin{array}{lll}\mathrm{O} 2-\mathrm{Si} 2 & -010 & 104.8(3) \\ & -08 & 112.9(3)\end{array}$

$\begin{array}{llll} & -010 & 103.5(3) \\ 08 & -\mathrm{Si2} & -010 & 110.7(3)\end{array}$

$06-P \quad-O 7 \quad 109.1(3)$

- $013 \quad 107.3(3)$

- OJ $109.0(4)$

$07-P \quad-013 \quad 107.4(4)$

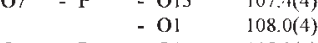

$013-\mathrm{P}-\mathrm{O} 1 \quad 115.9(4)$

basis to innelite, $\mathrm{Na}_{2} \mathrm{Ba}_{3}(\mathrm{Ba}, \mathrm{K})(\mathrm{Ca}, \mathrm{Na}) \mathrm{Ti}\left(\mathrm{TiO}_{2}\right)_{2}$ $\left(\mathrm{Si}_{2} \mathrm{O}_{7}\right)_{2}\left(\mathrm{SO}_{4}\right)_{2}$ (Chernov et al. 1971). The major structural difference between the two is that innelite contains both ${ }^{[5]} \mathrm{Ti}$ and ${ }^{[6]} \mathrm{Ti}$, occupying crystallographically distinct sites. The location of these sites in the crystal structure eliminates the center of symmetry, and results in that mineral adopting the noncentrosymmetric spacegroup $P 1$.

\section{DisCUSSION}

Yoshimuraite contains essentially ordered Si and P, as constrained by results from electron-microprobe analyses (Table 2), mean $T-\mathrm{O}$ bond distances (Table 4) and calculated bond-valence sums (Table 5). As such, it is recommended that this mineral be classified as a silicophosphate (McDonald et al. 1994). It should be noted, however, that yoshimuraite does contain a significant amount of $\mathrm{S}^{6+}$ (presumably substituting for $\mathrm{P}^{5+}$ ), which results in shorter observed cation-oxygen bond distances for $\mathrm{P}^{5+}$ and hence, higher bond-valence sums for $\mathrm{P}^{5+}$ and some of the associated bonding atoms of oxygen (Table 5).

Yoshimuraite is also a member of a large group of layered Ti- and Zr-bearing silicates and silicophosphates that have been collectively referred to as the $B M_{n}$ heterophyllosilicate polysomatic series (Ferraris et al. 1996). These minerals are generally restricted to silicadeficient hyperalkaline $[(\mathrm{Na}+\mathrm{K}) / \mathrm{Al}>>1]$ igneous rocks, which are enriched in incompatible elements that are able to proxy for $\mathrm{Si}^{4+}$, most notably ${ }^{\mathrm{VI}} \mathrm{Ti}^{4+}$ and ${ }^{\mathrm{VI}} \mathrm{Zr}^{4+}$. This results in the formation of unusual, exotic minerals whose structures possess strong similarities with those of more common minerals found in silicarich environments. For example, although chemically distinct, the above minerals are structurally relatable to 2:1 phyllosilicates. Their $a$ value is very similar or rationally related to the $a_{\text {mica }}$ value ( $c a$. $5.4 \AA$ ). They are also of low symmetry (monoclinic or triclinic), exhibit a perfect basal cleavage, and possess a strongly pseudohexagonal character.

The crystal chemistry and some of the topological relationships that exist among the members of the $B M_{n}$ heterophyllosilicate series have been discussed by Egorov-Tismenko \& Sokolova (1990) and Ferraris et al. (1996). In short, members of this series are 2:1 phyllosilicate-like minerals containing brucite-like $M \phi_{6}$ layers [M: $\mathrm{Mn}, \mathrm{Mg}, \mathrm{Fe} ; \phi$ : unspecified ligand, e.g., $\mathrm{O}^{2-}$, $\left.(\mathrm{OH})^{-}, \mathrm{F}^{-}\right]$bounded on two sides by heterophyllosilicate layers consisting of $\left(\mathrm{Si}_{2} \mathrm{O}_{7}\right)$ clusters linked by $\mathrm{Ti}$ and $\mathrm{Zr}$ polyhedra. The series ideally has two end-members, bafertisite $\left[\mathrm{BaFeTiO}\left(\mathrm{Si}_{2} \mathrm{O}_{7}\right)(\mathrm{OH})_{2}\right]$, which gives rise to a $B$ module $\left[(A, \square)_{2}(M, \square)_{4}\left(X_{2} T_{4} \mathrm{O}_{17}\right)(\mathrm{OH})_{2}\right.$, and dioctahedral mica, which gives rise to a $M$ module $\left[(A, \square)(M, \square)_{3}\left(T_{4} \mathrm{O}_{10}\right)(\mathrm{OH})_{2}\right]$. The $M$ module is given the subscript $n$ to denote the number of such modules present in a given member of the series. For example, bafertisite has $n=0$, astrophyllite $\left[(\mathrm{K}, \mathrm{Na})_{3} \mathrm{Fe}_{7} \mathrm{Ti}_{2} \mathrm{Si}_{8} \mathrm{O}_{28}\right.$ 
TABLE 5. EMPIRICAL BOND-VALENCES (v.u.) IN YOSHIMURAITE

\begin{tabular}{|c|c|c|c|c|c|c|c|c|c|c|}
\hline & $\mathrm{Ba}(1)$ & $\mathrm{Ba}(2)$ & $\operatorname{Mn}(1)$ & $\operatorname{Mn}(2)$ & $\operatorname{Mn}(3)$ & $\mathrm{Ti}^{*}$ & $\mathrm{Si}(1)$ & $\mathrm{Si}(2)$ & $\mathrm{P}$ & $\Sigma \mathrm{V}$ \\
\hline$O(1)$ & 0.330 & 0.197 & & & & & & & 1.248 & 1.977 \\
\hline & & 0.202 & & & & & & & & \\
\hline$O(2)$ & 0.234 & 0.155 & & & & 0.635 & & 1.041 & & 2.065 \\
\hline$O(3)$ & 0.150 & 0.142 & & & & 0.658 & 1.008 & & & 1.958 \\
\hline$O(4)$ & 0.157 & 0.148 & & & & 0.643 & 1.025 & & & 1.973 \\
\hline$O(5)$ & 0.229 & 0.147 & & & & 0.647 & & 1.044 & & 2.067 \\
\hline$O(6)$ & 0.383 & $\begin{array}{l}0.249 \\
0.273\end{array}$ & & & & & & & 1.444 & 2.349 \\
\hline$O(7)$ & 0.378 & $\begin{array}{l}0.269 \\
0.265\end{array}$ & & & & & & & 1.433 & 2.345 \\
\hline$O(8)$ & & & & $\begin{array}{l}0.300 \\
0.278\end{array}$ & $0.398^{\mathrm{X} 2}$ & & & 1.022 & & 1.998 \\
\hline$O(9)$ & & & $0.267^{\mathrm{X2}}$ & 0.429 & $0.227^{\mathrm{X} 2}$ & 1.073 & & & & 1.996 \\
\hline$O(10)$ & $\begin{array}{l}0.098 \\
0.089\end{array}$ & & & & & & 0.981 & 1.008 & & 2.176 \\
\hline OH( 11 & & & $0.351^{x 2}$ & 0.428 & $0.338^{\times 2}$ & & & & & 1.117 \\
\hline$O(12)$ & & & $0.368^{\mathrm{x} 2}$ & $\begin{array}{l}0.262 \\
0.303\end{array}$ & & & 1.011 & & & 1.944 \\
\hline$O(13)$ & $\begin{array}{l}0.096 \\
0.095\end{array}$ & 0.387 & & & & & & & 1.368 & 1.946 \\
\hline $2 \mathrm{~V}$ & 2.239 & 2.434 & 1.972 & 2.000 & 1.926 & 3.656 & 4.025 & 4.115 & 5.493 & \\
\hline
\end{tabular}

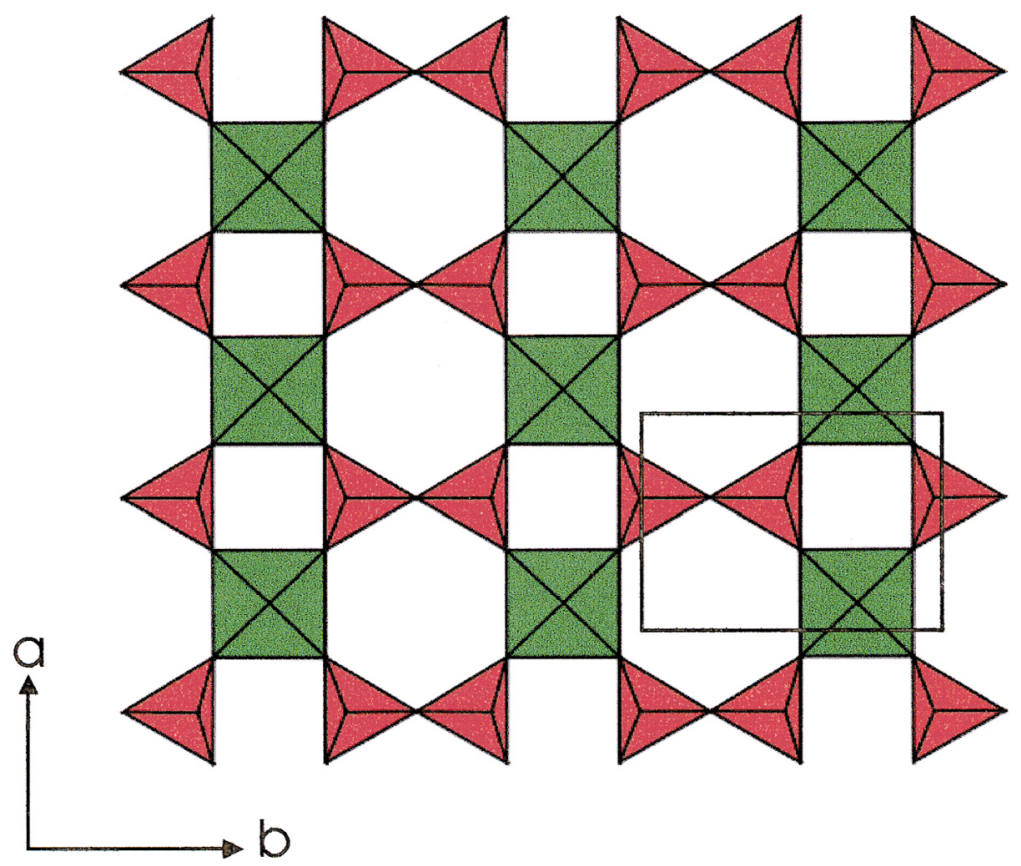

FIG. 1. Yoshimuraite, (001) heterophyllosilicate layer showing the $\mathrm{TiO}_{5}$ polyhedra (green) and the diorthosilicate groups (red). The unit cell is outlined. 


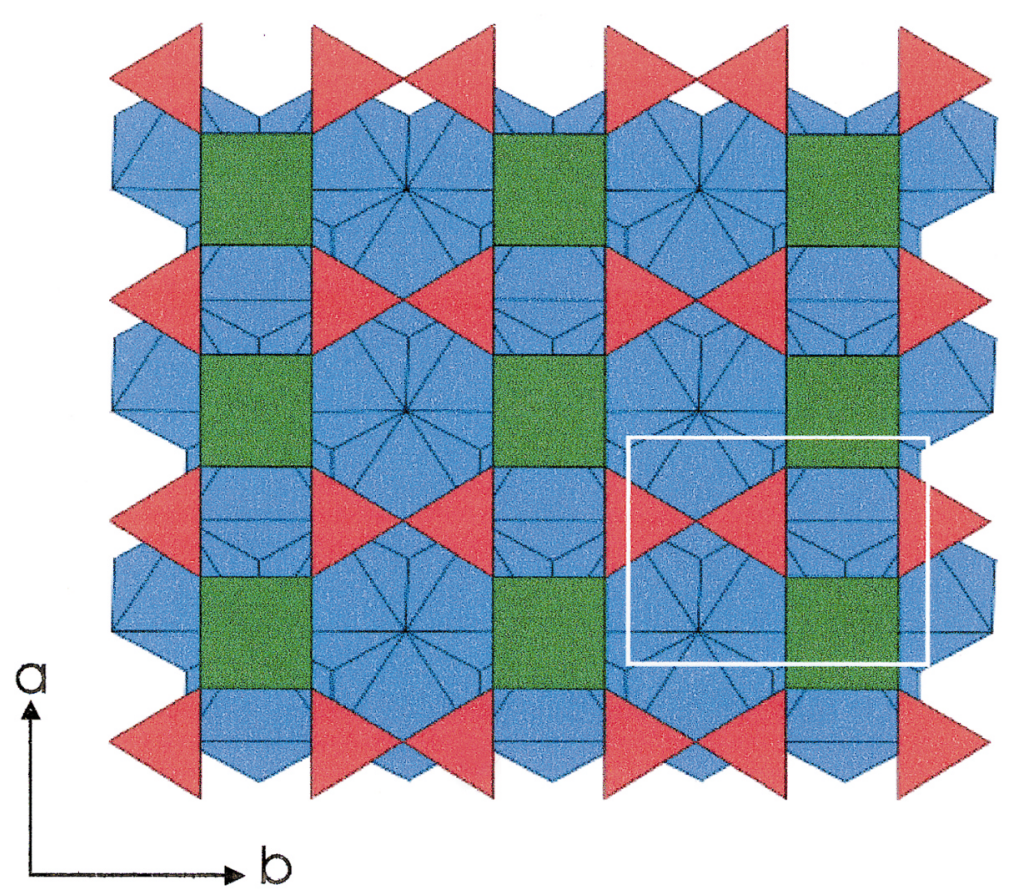

FIG. 2. Yoshimuraite, (001) heterophyllosilicate layer overlying the closest-packed Mn $\phi_{6}$ layer of octahedra (blue). The unit cell is outlined.

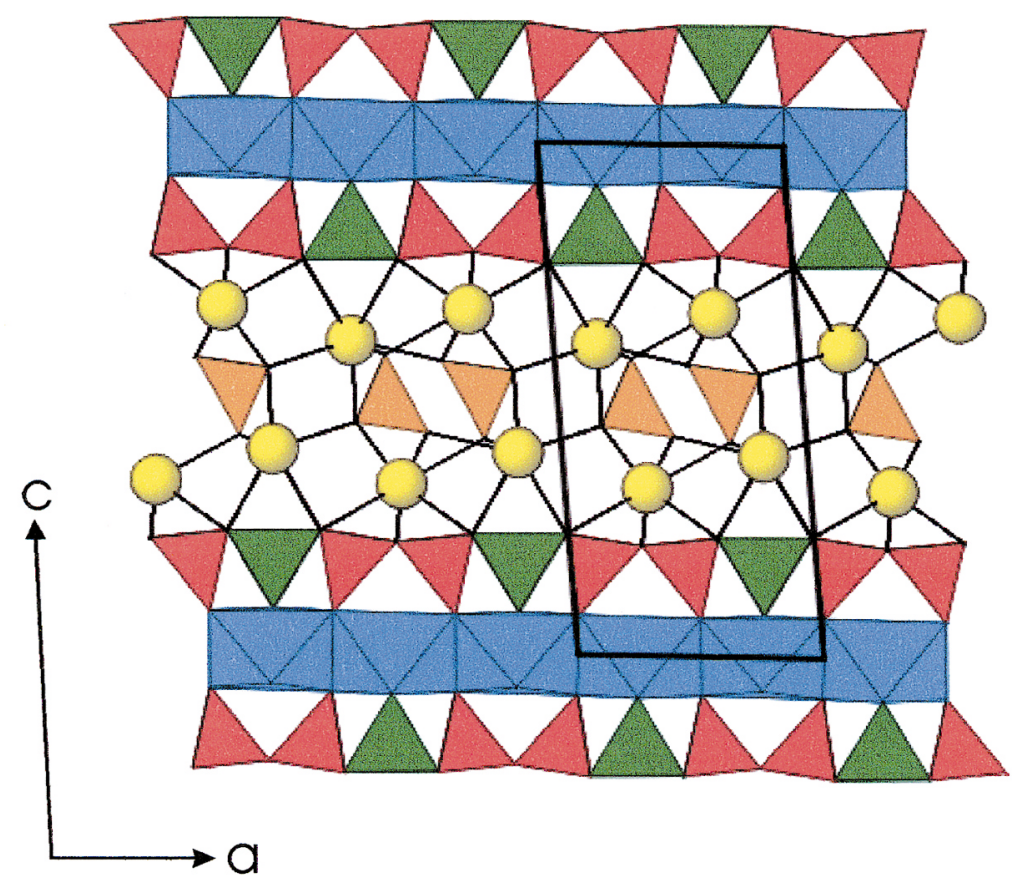

FIG. 3. Yoshimuraite, (010) plane showing the development of the 2:1 composite layers and the interlayer-like $\left[\mathrm{Ba}_{2}\left(\mathrm{PO}_{4}\right)\right]$ component. The $\mathrm{PO}_{4}$ tetrahedra are orange, and the $\mathrm{Ba}$ atoms are represented as yellow spheres. The unit cell is outlined. 
$\left.(\mathrm{OH}, \mathrm{O})_{3}\right]$ has $n=1$, and the mineral nafertisite $\left[(\mathrm{Na}, \mathrm{K})_{3}\left(\mathrm{Fe}^{2+}, \mathrm{Fe}^{3+}, \square\right)_{10}\left\{\mathrm{Ti}_{2} \mathrm{Si}_{12} \mathrm{O}_{37}\right\}(\mathrm{OH}, \mathrm{O})_{6}\right.$; Ferraris et al. 1996] has $n=2$. The $B M_{0}$ polysome of this series (i.e., bafertisite) can be further divided on the basis of the presence or absence of an interlayer component, and where present, its composition. Members of this subseries include minerals in which the interlayer space is vacant, as in seidozerite $\left[\mathrm{Na}_{4} \mathrm{MnTiZr}\left(\mathrm{Si}_{2} \mathrm{O}_{7}\right)_{2} \mathrm{O}_{2}\right.$ $\left.(\mathrm{F}, \mathrm{OH})_{2}\right]$, where alkalis or alkaline earths are present with or without $\mathrm{H}_{2} \mathrm{O}$, as in murmanite $\left[\mathrm{Na}_{3} \mathrm{Ti}_{4} \mathrm{O}_{4}\right.$ $\left(\mathrm{Si}_{2} \mathrm{O}_{7}\right)_{2} \bullet 4 \mathrm{H}_{2} \mathrm{O}$ ], with $\left(\mathrm{SO}_{4}\right)^{2-}$, as in innelite, or with $\left(\mathrm{PO}_{4}\right)^{3-}$, as in yoshimuraite.

The occurrence of ${ }^{[5]} \mathrm{Ti}$ in minerals such as yoshimuraite is unusual and worthy of comment. Titanium is the first member of the $d$-block transition elements and has four valence electrons. Although it can adopt several oxidation states, $\mathrm{Ti}^{4+}$ is by far the most common in minerals. As significant energy is required to remove the four electrons, $\mathrm{Ti}^{4+}$ compounds are generally highly covalent in character. The electronic configuration $d^{0}$ for $\mathrm{Ti}^{4+}$ gives rise to either [5]- or [6]- coordination in minerals. For [6]-coordination, the octahedral geometry has Ti-O bond lengths typically in the range of 1.91 to $1.95 \AA$. The occurrence of ${ }^{[5]} \mathrm{Ti}^{4+}$, as in yoshimuraite, is uncommon but has been recognized in a number of related phases, including lamprophyllite, $\left[\mathrm{Sr}_{2} \mathrm{Na}_{3} \mathrm{Ti}\right.$ $\left.(\mathrm{TiO})_{2}\left(\mathrm{Si}_{2} \mathrm{O}_{7}\right)(\mathrm{O}, \mathrm{OH}, \mathrm{F})_{2}\right]$, fresnoite, $\left[\mathrm{Ba}_{2} \mathrm{TiO}\left(\mathrm{Si}_{2} \mathrm{O}_{7}\right]\right.$ and innelite, $\left[\mathrm{Na}_{2} \mathrm{Ba}_{4} \mathrm{CaTi}\left(\mathrm{TiO}_{2}\right)_{2}\left[\mathrm{Si}_{2} \mathrm{O}_{7}\right]_{2}\left(\mathrm{SO}_{4}\right)_{2}\right]$. The $\mathrm{TiO}_{5}$ polyhedron may be best described as a square or tetragonal pyramid, with the apical $\mathrm{Ti}-\mathrm{O}$ distance being relatively short ( $c a .1 .68 \AA$ ) and the four basal bond distances being relatively long ( $c a .1 .98 \AA$ ). These bond distances and coordination geometry are in excellent agreement with those observed for ${ }^{[5]} \mathrm{Ti}$ in synthetic alkali titanosilicate glasses (1.67-1.70 $\AA$ and 1.94-1.96 $\AA$; Cormier et al. 1997). The short apical bond-length is indicative of $\pi$-bonding, whereas the other four bonds are consistent with $\sigma$-bond lengths.

Whereas it may seem contradictory to discuss $\mathrm{Ti}$ coordination polyhedra in terms of Lewis strengths (owing to the uncertainty of the degree of covalent character), certain generalities can be deduced to help elucidate the occurrence of ${ }^{[5]} \mathrm{Ti}^{4+}$ in nature. It is noteworthy that ${ }^{[5]} \mathrm{Ti}^{4+}$ occurs in crystal structures with a high concentration of large, low-valence cations that are weak Lewis acids; i.e. $\mathrm{Na}, \mathrm{Ca}, \mathrm{Sr}$ and $\mathrm{Ba}$. In keeping with the valence-matching principle, these structures are moderately to highly polymerized (sheet) silicates, which lowers the Lewis basicity. Casual thought may lead to the perception that lowering the coordination of Ti from [6] to [5] would increase the Lewis acidity, but the $s p^{3} d$ hybridization effectively shifts the Ti atom off the square equatorial plane of $\mathrm{O}$ atoms toward the apex of the pyramid. This shift lowers the bond valence (i.e., lowers the Lewis acidity) of the equatorial oxygen atoms, making them suitable for bonding to the alkali or alkaline-earth elements that form the interlayers in these heterophyllosilicates. Similar arguments can explain the same coordination observed for ${ }^{[5]} \mathrm{W}^{6+}$ in pinalite $\left[\mathrm{Pb}_{3} \mathrm{WO}_{5} \mathrm{Cl}_{2}\right]$ (Grice \& Dunn 1999), since W has the same electronic configuration, $d^{0}$, as ${ }^{[5]} \mathrm{Ti}^{4+}$. Furthering this concept, Grice et al. (1999) discussed other phases structurally related to pinalite and showed how the unique electronic character of $\mathrm{Pb}^{2+}$ and $\mathrm{Bi}^{3+}$, which have stereoactive lone-pair behavior, lowers the Lewis acidity to stabilize the formation of oxycarbonates and oxy-chlorides.

Whereas the above provides a rationale for the development of ${ }^{[5]} \mathrm{Ti}^{4+}$, it does not explain why $\mathrm{Ti}^{4+}$ can be [4]-, [5]- or [6]-coordinated in minerals. An answer to this may lie in the character of the melt structure from which Ti-bearing minerals crystallize. For example, ${ }^{[5]} \mathrm{Ti}^{4+}$ is probably the dominant species in systems where $\mathrm{TiO}_{2}$ levels are below rutile saturation, followed by ${ }^{[4]} \mathrm{Ti}^{4+}$ (Farges et al. 1996, Farges 1997). However, the actual coordination of $\mathrm{Ti}^{4+}$ is also influenced by a number of factors besides $\mathrm{TiO}_{2}$ content, including total alkalinity, Al content of the melt, etc. (Romano et al. 2000). In the system $\mathrm{Na}_{2} \mathrm{O}-\mathrm{SiO}_{2}-\mathrm{TiO}_{2}$, Henderson \& Fleet (1995) noted that ${ }^{[4]} \mathrm{Ti}^{4+}$ dominates at low $\mathrm{TiO}_{2}$ concentrations, but above $7.1 \mathrm{wt} \% \mathrm{TiO}_{2},{ }^{[5]} \mathrm{Ti}^{4+}$ is found to dominate instead. In alkali-depleted systems, ${ }^{[4]} \mathrm{Ti}^{4+}$ dominates at low $\mathrm{TiO}_{2}$ concentrations, with ${ }^{[6]} \mathrm{Ti}^{4+}$ dominating at high (>7 wt.\% $\mathrm{TiO}_{2}$ ) contents. However, in systems enriched in alkalis, notably those of large radii (e.g. $\mathrm{K}^{+}, \mathrm{Ba}^{2+}$, etc.) ${ }^{[5]} \mathrm{Ti}^{4+}$ dominates (Dingwell et al. 1994). Since Al tends to destabilize the local environment around ${ }^{[5]} \mathrm{Ti}^{4+}$ (resulting in formation of ${ }^{[4]} \mathrm{Ti}^{4+}$ ), low concentrations of $\mathrm{Al}$ also favor this coordination. As melts are polymerized to a certain extent, albeit on a short-range level, "crystal-like" fragments do exist, upon which minerals might nucleate in a template manner. It is plausible, therefore, that the coordination of $\mathrm{Ti}$ in minerals may be strongly influenced by the coordination of Ti dominant in the melt itself. Most hyper- to peralkaline igneous systems, such as those found at Mont Saint-Hilaire (Quebec, Canada), Ilímaussaq (Greenland) and the Khibina and Lovozero massifs (Russia), are characterized by high $\mathrm{Ti}$ and low $\mathrm{Al}$ contents, along with high alkalinities. Such factors tend to favor development and stabilization of ${ }^{[5]} \mathrm{Ti}^{4+}$ in the melt structures. Therefore, alkali titanosilicates found in these environments would be predicted to preferentially contain ${ }^{[5]} \mathrm{Ti}^{4+}$, with the presence of ${ }^{[6]} \mathrm{Ti}^{4+}$ possibly being favored by a selective Ti content or by the nature of the alkalis (i.e. the alkali field-strength; Gan et al. 1990).

\section{ACKNOWLEDGEMENTS}

We thank the following for their cooperation and support: F.C. Hawthorne, University of Manitoba, for use of the single-crystal diffractometer, P.C. Jones for the electron-microprobe analyses, and Mr. H.G. Ansell for providing the specimen used in this study. The authors also acknowledge the insightful comments 
provided by Dr. G. Ferraris and an anonymous reviewer. The work was partially supported by NSERC operating grants to AMM and GYC.

\section{REFERENCES}

Brese, N.E. \& O'KeEFFE, M. (1991): Bond-valence parameters for solids. Acta Crystallogr. B47, 192-197.

Chernov, A.N., Ilyukhin, V.V., Maksimov, B.A. \& Belov, N.V. (1971): Crystal structure of innelite, $\mathrm{Na}_{2} \mathrm{Ba}_{3}(\mathrm{Ba}, \mathrm{K}$, $\mathrm{Mn})(\mathrm{Ca}, \mathrm{Na}) \mathrm{Ti}\left(\mathrm{TiO}_{2}\right)_{2}\left(\mathrm{Si}_{2} \mathrm{O}_{7}\right)_{2}\left(\mathrm{SO}_{4}\right)_{2}$. Sov. Phys. Crystallogr. 16(1), 65-69.

Cormier, L., Gaskell, P.H., Calas, G., Zhao, J. \& Soper, A.K. (1997): The titanium environments in a potassium silicate glass measured by neutron scattering with isotopic substitution. Physica B 234, 393-395.

Dingwell, D.B., Paris, E., Seifert, F., Mottana, A. \& RomAnO, C. (1994): X-ray absorption study of Ti-bearing silicate glasses. Phys. Chem. Minerals 21, 501-509.

Egorov-Tismenko, Yu.K. \& Sokolova, E.V. (1990): Structural mineralogy of the homologous series seidozeritenacaphite. Mineral. Zh. 12(4), 40-49 (in Russ.).

FARGES, F. \& Brown, G.E., JR. (1997): Coordination chemistry of Ti(IV) in silicate glasses and melts: XANES study of synthetic and natural volcanic glasses and tektites at ambient temperature and pressure. Geochim. Cosmochim. Acta 61, 1863-1870.

Navrotsky, A., Gan, H. \& Rehr, J.J. (1996): Coordination chemistry of Ti(IV) in silicate glasses and melts. II. Glasses at ambient temperature and pressure. Geochim. Cosmochim. Acta 60, 3039-3053.

Ferraris, G., Ivaldi, G., Khomyakov, A.P., Soboleva, S.V., Belluso, E. \& Pavese, A. (1996): Nafertisite, a layer titanosilicate member of a polysomatic series including mica. Eur. J. Mineral. 8, 241-249.
Gan, H., Wilding, M.C. \& NATrotsky, A. (1996): $\mathrm{Ti}^{4+}$ in silicate melts: energetics from high- temperature calorimetric studies and implications for melt structure. Geochim. Cosmochim. Acta 60, 4123-4131.

Grice, J.D., CoOper, M.A. \& HAwthorne, F.C. (1999): Crystal-structure determination of twinned kettnerite. Can. Mineral. 37, 923-927.

\& DunN, P.J. (2000): Crystal-structure determination of pinalite. Am. Mineral. 85, 806-809.

Henderson, G.S. \& FleEt, M.F. (1995): The structure of Ti silicate glasses by micro-Raman spectroscopy. Can. Mineral. 33, 399-408.

HiLL, R.J. (1977): A further refinement of the barite structure. Can. Mineral. 15, 522-526.

McDonald, A.M., Chao, G.Y. \& Grice, J.D. (1994): Abenakiite-(Ce), a new silicophosphate carbonate mineral from Mont Saint-Hilaire, Quebec: description and structure determination. Can. Mineral. 32, 843-854.

North, A.C.T., Phillips, D.C. \& Mathews, F.S. (1968): A semi-empirical method of absorption correction. Acta Crystallogr. A24, 351-359.

Romano, C., Paris, E., Poe, B.T., Giuli, G., Dingwell, D.B. \& Mottana, A. (2000): Effect of aluminum on Ti-coordination in silicate glasses: a XANES study. Am. Mineral. 85, 108-117.

SHELDRICK, G.M. (1990): SHELXTL, a Crystallographic Computing Package (revision 4.1). Siemens Analytical X-ray Instruments, Inc., Madison, Wisconsin.

Watanabe, T., TAKÉUChI, Y. \& ITO, J. (1961): The minerals of the Noda-Tamagawa mine, Iwaté Prefecture, Japan. III. Yoshimuraite, a new barium-titanium-manganese silicate mineral. Mineral. J. 3, 156-167.

Received September 8, 1997, revised manuscript accepted February 29, 2000. 